\title{
BioLink
}

Jurnal Biologi Lingkungan, Industri, Kesehatan

Available online http://ojs.uma.ac.id/index.php/biolink

\section{DAYA HAMBAT DAUN MANUKAN (Rhinacanthus nasutus (L) Kurz) TERHADAP BAKTERI STAPHYLOCOCCUS AUREUS SECARA IN VITRO \\ INHIBITION OF MANUKAN LEAVES (Rhinacanthus nasutus (L) Kurz) AGAINST STAPHYLOCOCCUS AUREUS BACTERIA VIA IN VITRO}

\author{
Sunarti ${ }^{*}$ dan Debora Paninsari ${ }^{2}$
}

1Departemen Ilmu Biomedik Fakultas Keperawatan \& Kebidanan Universitas Prima Indonesia 2Depatemen Ilmu Kebidanan Fakultas Keperawatan \& Kebidanan Universitas Prima Indonesia

Diterima : 19-07-2019; Disetujui : 12-11-19: Diterbitkan : 10-02-2020

${ }^{*}$ Corresponding author: E-mail: unartibiomed@gmail.com

\section{Abstrak}

Penggunaan antimikroba secara komersial, bebas dan tanpa pengawasan masih cukup tinggi di Indonesia. Hal ini dapat meningkatkan angka kesakitan dan kejadian resistensi obat. Staphylococcus aureus merupakan bakteri patogen yang sangat berbahaya terutama menginfeksi secara supuratif pada kulit. Kejadian resistensi terhadap berbagai jenis antibiotik dapat terjadi pada bakteri tersebut, sehingga mempersulit penentuan antimikroba yang sesuai untuk terapi. Hal ini penting mencari alternatif dari bahan alam yang dapat dijadikan sebagai terapi. Daun manukan (Rhinacanthus nasutus (L) Kurz) memiliki zat aktif rinacanthin dapat digunakan sebagai anti bakteri. Penelitian ini bertujuan mengetahui daya hambat ekstrak etanol daun manukan terhadap bakteri Staphylococcus aureus secara in vitro kosentrasi ekstrak 15, 30 dan 60\% dengan kelompok kontrol. Penelitian ini true eksperiment melalui uji in vitro dengan metode Kirby Bauer. Hasil penelitian didapatkan diameter rata-rata zona hambat pada konsentrasi ekstrak 15, 30, dan 60\% adalah 9.97 mm, 10.95 mm, dan $13.18 \mathrm{~mm}$. Hasil uji Kruskal-Wallis menunjukkan adanya perbedaan bermakna antara keempat kelompok perlakuan $(\mathrm{P}=0.010)$. Hasil uji Mann-Whitney terdapat perbedaan bermakna zona hambat antara kelompok kontrol dengan kelompok perlakuan pada kosentrasi 15, 30 dan 60\% dengan nilai masing-masing $\mathrm{p}=(0.037)$. Hal ini menunjukkan bahwa ekstrak etanol daun manukan efektif terhadap daya hambat pertumbuhan bakteri Staphylococcus aureus.

Kata Kunci: Ekstrak daun manukan, Zona hambat, Staphylococcus aureus

\begin{abstract}
The use of antimicrobial, such as antibiotics against infectious diseases with no control is quite common in Indonesia. This leads to increase morbidity and incidence of drug resistance. Staphylococcus aureus is a pathogenic bacteria, particularly infects the skin. The resistance it difficult to determine which antimicrobials were suitable for therapy. Manukan leaves have an active substance Rhinacanthin can be used as an anti-bacterial. This study aimed to determine the inhibition of ethanol extract of manukan leaves (Rhinacanthus nasutus (L) Kurz) against gram-positive bacteria (Staphylococcus aureus) in vitro with the extract concentration of 15, 30, and 60\% as a control. This study was a true experiment through the in vitro test with the Kirby Bauer method. The results showed that the average diameter of the inhibition zone was at an extract concentration of 15, 30, and $60 \%$ are $9.97 \mathrm{~mm}, 10.95 \mathrm{~mm}$, and $13.18 \mathrm{~mm}$. The Kruskal-Wallis test results showed a significant difference between the four treatment groups ( $p=$ 0.010). The Mann-Whitney test showed significant differences in the inhibition zone between control and treatment at 15, 30 and 60\% ( $p=0.037)$. In conclusion leave, ethanol extract of manukan has antimicrobial activity in inhibiting staphylococcus aureus.
\end{abstract}

Key Words: Manukan leaf extract, Inhibitory zone, Staphylococcus aureus

How to Cite: Sunarti dan Paninsari, D. (2020). Daya Hambat Daun Manukan (Rhinacanthus nasutus (L) Kurz) Terhadap Bakteri Staphylococcus aureus Secara In Vitro, BioLink: Jurnal Biologi Lingkungan, Industri dan Kesehatan, Vol.6 (2): Hal. 106-113 
Sunarti dan Paninsari, D. Daya Hambat Daun Manukan (Rhinacanthus nasutus (L) Kurz) Terhadap Bakteri Staphylococcus aureus Secara In Vitro

PENDAHULUAN

Penyakit infeksi merupakan penyakit yang diakibatkan masuknya mikro-organisme di dalam tubuh dengan manifestasi klinik berupa kerusakan jaringan atau reaksi radang. Penyebaran sumber infeksi ini dapat melalui berbagai perantara (vektor) seperti udara, benda maupun binatang (Dessy, 2014).

Penyebaran penyakit infeksi cukup tinggi sehingga penyakit ini masih menempati urutan pertama di dunia sebagai penyebab terjadinya angka kesakitan dan kematian yakni antara 10 sampai 30 orang per 100.000 orang pertahun (Tong et al, 2015).

Staphylococcus aureus merupakan bakteri gram positif dapat menimbulkan infeksi supuratif pada kulit, sendi dan tulang bahkan penyebab utama endokarditis infektif. Bakteri ini menghasilkan beberapa toksin penghancur membran yang mampu merusak eritrosit, lekosit, trombosit sel manusia (Pringoutomo et al., 2012).

Penelitian sebelumnya menemukan bahwa diameter zona hambat Staphylococcus aureus menurun, yang menunjukkan bahwa komponen polifenol pada tanaman herbal memiliki aktifitas antimikroba terhadap bakteri gram positif dan gram negatif (Hardana et al., 2016).

Daun manukan (Rhinacanthus nasutus (L) Kurz) merupakan tanaman dari famili Acanthaceae yang paling dikenal dan merupakan tanaman obat terkenal di India, Cina dan serta Asia Tenggara termasuk Thailand (Antonysamy, 2017).

Daun manukan memiliki zat aktif rinacanthin dan zat aktif metabolit sekunder seperti flavonoid, benzenoid, coumarin, anthraquinon, quinon, glycosid, carbohydrat, triterpen, steroid, anthraquinon, napthoquinon, saponin, tannin, phenolic dan alkaloid. Alkaloid dan rinacanthin yang diisolasi dari Rhinacanthus nasutus memiliki aktivitas antibakteri (Bukke, et al, 2011).

Penelitian sebelumnya menemukan ekstrak metanol Rhinacanthus nasutus menunjukkan aktivitas yang signifikan melawan Staphylococcus aureus dan Klebsiella pneumonia pada kosentrasi 2\% (Shoba \& Jayapriya, 2015).

Penelitian sebelumnya dengan pengujian ekstrak metanol Rhinacanthus nasutus kosentrasi $20 \mathrm{mgml}^{-1}$ dengan Staphylococcus aureus, Escherichia coli, Klebsiella pneumonia, Pseudomonas aeruginosa, Proteus vulgarius dan Candida albicans hanya menunjukkan nilai aktifitas yang signfikan pada Staphylococcus aureus (Rajasekaran et al, 2009).

Penelitian sebelumnya juga menunjukan ekstrak etanol Rhinacanthus nasutus efektif dalam menghambat aktifitas bakteri Bacillus subtilis dan 
Salmonella paratyphi pada kosentrai 5 dan 10\% (Nanthakumar et al, 2014).

Penelitian ini penting dilakukan karena memiliki urgensi yang tinggi yakni penggunaan antimikroba secara komersial, bebas tanpa pengawasan pada pengobatan penyakit infeksi telah berkembang saat ini sehingga terjadi peningkatan resistensi obat. Selain itu penggunaan antibiotik dikaitkan dengan efek samping termasuk hipersensitivitas, imunosupresi dan reaksi alergi. Akibat efek samping dan resistensi obat pada mikroganisme patogen maka perlu alternatif lain dari komponen isolat biologi terutama ekstrak tanaman sebagai obat herbal (Singh et al, 2017). Selain itu angka kesakitan dengan penyakit infeksi dapat menurunkan produktifitas kerja, meningkatkan pengeluaran secara financial dan dapat menyebabkan penyakit kronis. Sehingga diharapkan hasil penelitian ini dapat menurunkan angka kesakitan dengan menurunkan status infeksi dari bakteri garam positif serta membantu menurunkan kejadian resistensi obat.

Pentingnya penggunaan obat herbal sebagai anti mikroba, dan beberapa penelitian belum menunjukkan hasil yang signifikan pada bakteri gram positif maka peneliti tertarik untuk melakukan penelitian ini. Penelitian ini bertujuan untuk mengetahui aktifitas anti mikroba ekstrak etanol daun manukan (Rhinacanthus nasutus (L) Kurz) terhadap bakteri gram positif (Staphylococcus aureus) secara in vitro pada kosentrasi ekstrak 15, 30 dan 60\%.

\section{METODE PENELITIAN}

Penelitian ini true experiment menggunakan metode Kirby Bauer dengan pemberian ekstrak etanol daun manukan pada media NA (Nutrient Agar) yang telah diinkubasi bakteri Staphylococcus aureus pada konsentrasi ekstrak 15, 30 dan 60\% ( $\left.\mathrm{P}_{1}, \mathrm{P}_{2}, \mathrm{P}_{3}\right)$, Sedangkan kelompok kontrol negatif dengan menggunakan aquabidest $\left(\mathrm{K}_{0}\right)$ dan kontrol positif dengan menggunakan kertas cakram kloranfenikol (K1) (Dahlan, 2011). Pengujian dilakukan dengan 3 kali pengulangan. Penelitian dilakukan di Laboratorium Farmasi USU dan Laboratorium Biologi Molekuler FK UNPRI.

\section{Persiapan Ekstrak Daun Manukan}

Material daun manukan berasal dari Desa Pasar Gunung Kec. Secanggang Kab. Langkat. Daun manukan pertama dikeringkan menggunakan lemari pengering suhu $60^{\circ} \mathrm{C}$, kemudian diblender. Serbuk halus $1 \mathrm{~kg}$ di larutkan dengan 10 liter etanol 96\% (1:10). Ekstraksi dengan maserasi pelarut etanolm 96\%. Ekstrak didiamkan selama 72jam ( $3 \times 24$ jam) diaduk, filtrat disaring menggunakan 
Sunarti dan Paninsari, D. Daya Hambat Daun Manukan (Rhinacanthus nasutus (L) Kurz) Terhadap Bakteri Staphylococcus aureus Secara In Vitro

kertas saring, lalu filtrat diuapkan steril dan diinkubasi pada temperatur menggunakan vakum rotary evaporator pada temperatur $50-60^{\circ} \mathrm{C}$ hingga 37ํㅡ selama 36-48 jam. Kertas cakram diperoleh ekstrak kental. Kemudian diencerkan dengan aquabidest steril dengan rumus pengenceran $\mathrm{N}_{1} \times \mathrm{V}_{1}=\mathrm{N}_{2}$ $\mathrm{xV}_{2}$ dimana $\mathrm{N}_{1}=$ kosentrasi awal dan $\mathrm{V}_{1}=$ volume awal, $\mathrm{N}_{2}=$ Kosentrasi akhir dan $\mathrm{V}_{2}=$ Volume akhir (Abdullatif, 2016).

\section{Persiapan Bakteri Staphylococcus aureus dan Prosedur Eksperimen}

Isolat Staphylococcus aureus diperoleh dari Laboratorium Mikrobiologi USU. Pembuatan suspensi bakteri dengan cara mengambil masing-masing satu koloni murni bakteri Staphylococcus aureus. Koloni dibuat suspensi pada tabung reaksi yang berisi $\mathrm{NaCl}$ 0,9\% (fisiologis) dengan menggunakan ose mata, kemudian divortek supaya homogen. Kekeruhan suspensi disamakan dengan larutan standar Mc Farland 0,5 agar diperoleh bakteri sebanyak $1,5 \times 10^{8} \mathrm{sel} / \mathrm{mL}$. Suspensi tersebut kemudian dimasukkan ke dalam media BHI (Brain Heart Infusion) cair dalam tabung reaksi, kemudian diinkubasi dengan temperatur $37^{\circ} \mathrm{C}$ selama 6-10 jam. Kemudian suspensi diinkubasi pada media MSA (Manitol Salt Agar), diinkubasi pada temperatur $37^{\circ} \mathrm{C}$ selama 24 jam. Selanjutnya siapkan media NA (Nutrient Agar) dan diusapkan biakan bakteri Staphylococcus aureus dengan lidi kapas 


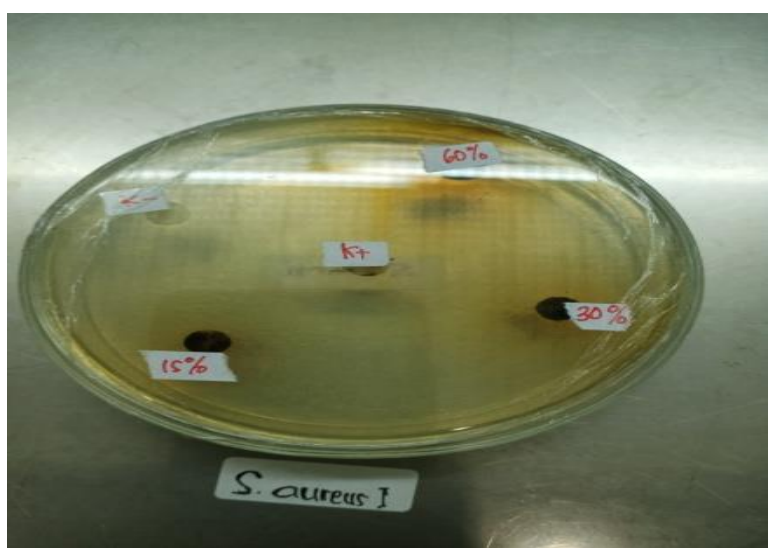

(a)

Gambar a. Pengulangan pertama: zona hambat bakteri Staphylococcus aureus yang terbentuk adalah: $\mathrm{K} 0=0, \mathrm{~K} 1=0, \mathrm{P} 1=10.25 \mathrm{~mm}, \mathrm{P} 2=10.65 \mathrm{~mm}$, $\mathrm{P} 3=15.10 \mathrm{~mm}$

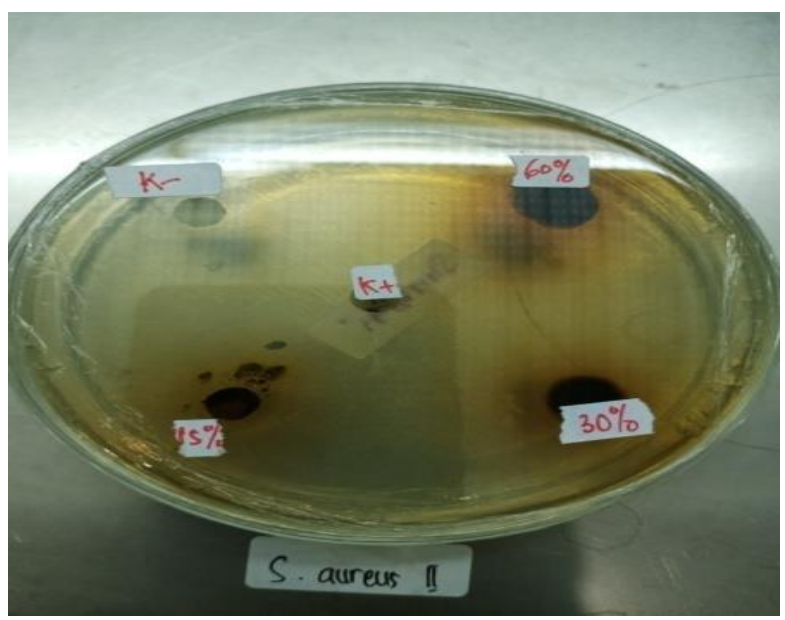

(b)

Gambar b. Pengulangan kedua: zona hambat bakteri Staphylococcus aureus yang terbentuk adalah: $\mathrm{K} 0=0, \mathrm{~K} 1=0, \mathrm{P} 1=9.75 \mathrm{~mm}, \mathrm{P} 2=10.25 \mathrm{~mm}$, $\mathrm{P} 3=11.45 \mathrm{~mm}$

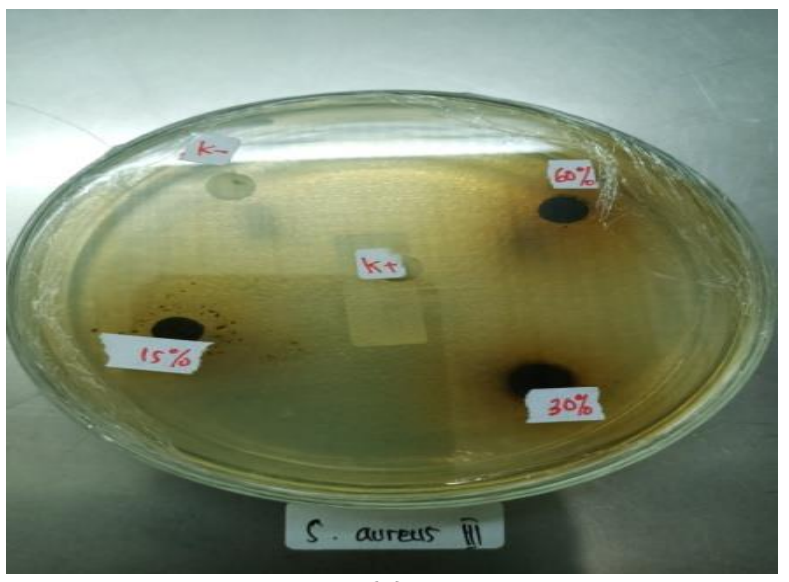

(c)

Gambar c. Pengulangan ketiga: zona hambat bakteri Staphylococcus aureus yang terbentuk adalah: $\mathrm{K} 0=0, \mathrm{~K} 1=0, \mathrm{P} 1=9.90 \mathrm{~mm}, \mathrm{P} 2=11.95 \mathrm{~mm}$, P3=13.00 mm
Nilai rata-rata zona hambat pada aktifitas anti mikroba ekstrak etanol daun manukan terhadap bakteri Staphylococcus aureus secara in vitro dengan konsentrasi 15, 30 dan 60\% dapat dilihat dibawah ini.

Tabel 1. Nilai rata-rata zona hambat pada bakteri Staphylococcus aureus

\begin{tabular}{llcl}
\hline No & Kelompok & $\begin{array}{c}\text { Rata-Rata } \\
\text { Zona Hambat }\end{array}$ & Keterangan \\
& Perlakuan & (Mean) & \\
\hline 1. & K0 & 0 & Tidak ada \\
2. & K1 & 0 & Tidak ada \\
3. & P1 & 9.97 & Tidak ada \\
4. & P2 & 10.95 & Lemah \\
5. & P3 & 13.18 & Lemah \\
\hline
\end{tabular}

Keterangan: $K_{0}$ (kontrol negatif: Aquadest), $K_{1}$ (Kontrol positif: Kloramfenicol), P1(Kosentrasi ekstrak 15\%), $\mathrm{P}_{2}$ (Kosentrasi ekstrak 30\%), dan P3 (Kosentrasi ekstrak 60\%)

Data di uji dengan SPSS 25. Pada pengujian normalitas, uji Shapiro-Wilk ditemukan bahwa data pada kelompok mempunyai sebaran yang tidak normal dengan nilai $\mathrm{p}=0.002$ atau $(\mathrm{p}<0.05)$, maka sebagai alternatif dipilih uji KruskalWallis.

Uji Kruskal Wallis ditemukan terdapat perbedaan yang signifikan pada zona hambat Staphylococcus aureus dengan nilai $(\mathrm{p}=0.010)$ Untuk mengetahui kelompok mana yang mengalami perbedaan dari hasil pengukuran ini, maka dilakukan uji MannWhitney. Hasil uji akan ditunjukkan dengan perbedaan notasi pada masingmasing kelompok dengan nilai signifikansi $\alpha<0.05$. 
Sunarti dan Paninsari, D. Daya Hambat Daun Manukan (Rhinacanthus nasutus (L) Kurz) Terhadap Bakteri Staphylococcus aureus Secara In Vitro

Hasil uji Mann Whitney (Tabel 1.), terdapat zat aktif seperti Rhinacanthin-C ditemukan perbedaan secara signifikan yang diekstraksi dari daun dan akar antara kelompok kontrol dengan tanaman yang merupakan ester perlakuan kosentrasi 15, 30 dan 60\% naphthoquinone telah terbukti dengan nilai masing-masing $\mathrm{p}=(0.037)$. menghambat ekspresi NF- $\kappa \mathrm{B}$ sebagai anti Hal ini menunjukkan peningkatan secara inflamatori sel, anti cancer serta memiliki signifikan zona hambat ekstrak etanol aktivitas lainnya sebagai anti jamur, daun manukan (Rhinacanthus nasutus (L) antibakteri, antivirus, dan sitotoksik Kurz) terhadap bakteri gram positif (Boueroy et al, 2018).

(Staphylococcus aureus).

Hasil penelitian ini menunjukkan bahwa ekstrak etanol daun manukan mengandung metabolit sekunder seperti alkaloid, flavonoid, saponin, tanin, steroid dan triterpen. Hal ini sesuai dengan hasil penelitian sebelumnya melalui metode High Performance Liquid Chromatography (HPLC) ditemukan senyawa aktif yang tinggi seperti flavonoid yang dapat digunakan sebagai bahan aktif yang berpotensi sebagai obat baru dari tanaman Rhinacanthus nasutus (Raj et al, 2015).

Rhinacanthus nasutus juga memiliki zat aktif seperti naphthoquinone, rhinacanthins (A-D, G-Q), rhinacanthone yang secara farmakologis terkait dengan konstituen aktifnya dapat digunakan sebagai pengobatan eksim, TBC paru-paru, herpes, hepatitis, diabetes, hipertensi, dan berbagai penyakit kulit lainnya (Raina et al, 2014).

Penelitian sebelumnya juga Hasil penelitian yang ditemukan bahwa Rhinacanthus nasutus dapat digunakan sebagai antibakteria alami juga didukung dari hasil penelitian sebelumnya menemukan bahwa salep Rhinacanthus nasutus dengan konsentrasi hambat minimum (MIC) $250.000 \mu \mathrm{g} / \mathrm{mL}$ dan konsentrasi bakterisida minimum (MBC) $125.000 \mu \mathrm{g} / \mathrm{mL}$ dengan metode dilusi in vitro dapat menghambat pertumbuhan Staphylococcus aureus sehingga berpotensi sebagai obat alternatif untuk penyakit kulit karena memiliki kemampuan sebagai antibakteri (Lukiati et al, 2019).

Hasil penelitian ini juga didukung dari hasil penelitian sebelumnya yang meneliti bahwa Rhinacanthus nasutus memiliki sifat sebagai antioksidan, anti inflamasi, anti-proliferatif dan antimikroba yang signifikan dengan aplikasi nanopartikel yang disintesis dan dikarakterisasi dengan teknik UV, SEM, XRD dan FTIR (Giridharan et al, 2014).

menemukan bahwa Rhinacanthus nasutus 
Berdasarkan hasil penelitian zona hambat pada kelompok kontrol (Ko) dengan menggunakan aquabidest tidak menunjukkan adanya zona hambat pada bakteri Staphylococcus aureus hal ini karena aquabidest tidak memiliki efek antibakteri sehingga kelompok ini yang nantinya di bandingkan dengan ekstrak daun manukan kosentrasi 15, 30 dan 60\%. Namun dari hasil pengamatan zona hambat berdasarkan klasifikasi respon hambat bakteri masih tergolong lemah hal ini dapat dipengaruhi oleh peningkatan resistensi pada bakteri Staphylococcus aureus tersebut atau mungkin perlu peningkatan jumlah kosentrasi yang lebih tinggi untuk mendapatkan efek dosis (ED) yang efektif. Begitu juga pada kelompok kontrol positif dengan menggunakan kloramfenikol ditemukan hasil pengukuran zona hambat di sekitar kertas cakram dengan nilai 0 , hal ini mungkin dikarenakan bakteri telah mengalami resisten dengan kloramfenikol atau kemungkinan kloramfenikol tidak mampu menghambat perkembangan bakteri gram positif.

\section{SIMPULAN}

Hasil penelitian menunjukkan bahwa terjadi peningkatan secara signifikan zona hambat ekstrak etanol daun manukan (Rhinacanthus nasutus (L) Kurz) terhadap bakteri gram positif (Staphylococcus aureus) pada kosentrasi ekstrak daun manukan 15, 30 dan 60\%.

\section{UCAPAN TERIMA KASIH}

Peneliti mengucapkan terimakasih kepada: Seluruh staff Laboratorium Farmasi USU dan Laboratorium Biologi Molekuler FK UNPRI yang telah membantu pelaksanaan penelitian. Universitas Prima Indonesia yang telah memberikan dukungan kepada peneliti. Spesial buat Ditjen DIKTI yang telah memberikan hiba PDP (Penelitian Dosen Pemula)

\section{DAFTAR PUSTAKA}

Abdullatif. (2016). Daya Hambat Ekstrak Rimpang Kunyit (Curcuma domestica Val.) Terhadap Pertumbuhan Staphylococcus aureus Dan Staphylococcus epidermidis Secara In Vitro. Skripsi. Universitas Muhamadiyah Semarang Aminah, S. (2016). Perbandingan Daya Hambat Ekstrak Daun Jarak Pagar (Jatrophacurcas Linn) Terhadap Pertumbuhan Bakteri Staphylococcus aureus Dan Escherichia coli Secara In Vitro. Skripsi. FK Universitas Lampung

Antonysamy, J. (2017). In Vitro Phytochemical and Antibacterial Studies on Rhinacanthus Nasutus (L.) Kurz - A Medicinally Important Plant. Journal of Microbiology $\mathcal{E}$ Experimentation, 4(2), 2-5.

Boueroy, P., Saensa-Ard, S., Siripong, P., Kanthawong, S., \& Hahnvajanawong, C. (2018). Rhinacanthin-C extracted from Rhinacanthus nasutus (L.) inhibits cholangiocarcinoma cell migration and invasion by decreasing MMP-2, uPA, FAK and MAPK pathways. Asian Pacific Journal of Cancer Prevention, 19(12)

Bukke, S., Raghu, P. S., Sailaja, G., \& Kedam, T. R. (2011). The study on morphological, phytochemical and pharmacological aspects of Rhinacanthus nasutus. (L) kurz (A review). Journal of Applied Pharmaceutical 
Sunarti dan Paninsari, D. Daya Hambat Daun Manukan (Rhinacanthus nasutus (L) Kurz) Terhadap Bakteri Staphylococcus aureus Secara In Vitro

Science, 1(8), 26-32.

Dahlan, M. S. (2011). Statistik untuk Kedokteran dan Kesehatan Edisi 5. Jakarta: Salemba Medika pp. 20-40

Dessy, T. (2014). Frekuensi $\beta$-Lactamase Hasil Staphylococcus aureus Secara Iodometri Di Laboratorium Mikrobiologi Fakultas Kedokteran Universitas Andalas. Journal Gradien, 10(2), 992-995.

Giridharan, T., Chandran, M., Sindhu, S., \& Arumugam, P. (2014). Comparative studies on green synthesis and therapeutic applications of silver nano particles using Flacourtia sepiaria and Rhinacanthus nasutus. International Journal of Pharma and Bio Sciences, 5(4), B560-B569.

Hardana, H., Salim, U., Studi, P., Dokter, P., Kedokteran, F., Lampung, U., \& Lampung, B. (2016). Pengaruh Aktivitas Antimikroba Ekstrak Bawang Putih (Allium sativum) terhadap bakteri gram positif (Staphylococcus aureus). Skripsi. FK Universitas Lampung

Lukiati, B., Nugrahaningsih, Prabaningtyas, S., Aribah, D., \& Nur Arifah, S. (2019). Antibacterial Activity of Rhinacanthus nasutus L. Kurz ointment to Inhibit Staphylococcus aureus Growth Using in Vitro Dilution Method. IOP Conference Series: Earth and Environmental Science, $276(1)$.

Nanthakumar, R., Ashadevi, V., Arumugasamy, K., \& Shalimol, A. (2014). in Vitro Antimicrobial Activity of Aqueous and Ethanol Extracts of Rhinacanthus Nasutus- a Medicinal Plant, IJPCBS, 4(1), 164-166.
Pringoutomo, S.,Himawan, S., Tjarta, A, (2012), Buku Ajar Patologi I (Umum) Edisi I Revisi. Jakarta: FK UI pp107-109

Raina, H., Soni, G., Jauhari, N., Sharma, N., \& Bharadvaja, N. (2014). Phytochemical importance of medicinal plants as potential sources of anticancer agents. Turkish Journal of Botany, 38(6), 1027-1035.

Raj, V. B., Kumar, S. S., \& Kumar, K. L. S. (2015). HPTLC Standardization and Quantification of Rhinacanthus nasutus. Journal of Medicinal Plants Studies, 3(6), 51-55.

Rajasekaran, A., Sundaranadavalli, S., \& Murugesan, S. (2009). Antibacterial and antifungal evaluation of the leaves of Rhinacanthus nastus linn. International Journal of ChemTech Research, 1(3), 574-576.

Shoba, G. F., \& Jayapriya, G. (2015). Phytochemical analysis and antimicrobial efficacy of Rhinacanthus nasutus (l) Linn. Journal of Pharmacognosy and Phytochemistry, 3(6), 83-86.

Singh, N., Gupta, S., \& Rathore, V. (2017). Comparative antimicrobial study of ethanolic extract of leaf and rhizome of curcuma longa linn. Pharmacognosy Journal, 9(2), 208-212.

Tong, S. Y. C., Davis, J. S., Eichenberger, E., Holland, T. L., \& Fowler, V. G. (2015). Staphylococcus aureus infections: Epidemiology, pathophysiology, clinical manifestations, and management. Clinical Microbiology Reviews, 28(3), 603-661. 